Copyright () 2015 by Academic Publishing House Researcher

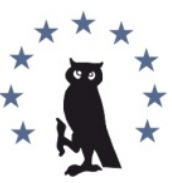

Published in the Russian Federation

European Researcher

Has been issued since 2010 .

ISSN 2219-8229

E-ISSN 2224-0136

Vol. 93, Is. 4, pp. 307-311, 2015

DOI: $10.13187 /$ er.2015.93.307

www.erjournal.ru

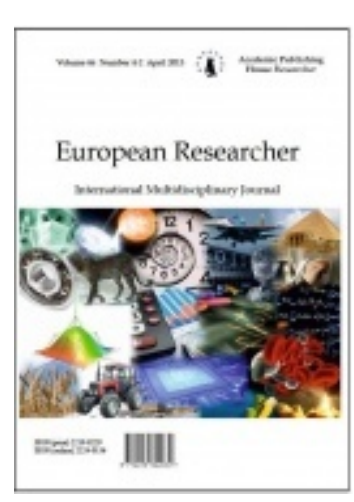

UDC 82.09"19"(574)

\title{
The Aesthetics of Postmodernism in Didar Amantay's Work
}

\author{
1 Sarzhan Takirov \\ ${ }^{2}$ Adil Zhakulaev \\ 3 Zhazira Altynbekova
}

\author{
${ }^{1}$ Academician E.A. Buketov Karaganda State University, Kazakhstan \\ $\mathrm{PhD}$ \\ ${ }^{2}$ Academician E.A. Buketov Karaganda State University, Kazakhstan \\ Master of Science \\ ${ }^{3}$ Nazarbayev Intellectual School Karaganda, Kazakhstan \\ Master of Science \\ E-mail: sarzhan68@mail.ru
}

\begin{abstract}
In the article the manifestation of postmodernism, originating in the sixties of the XX century having soaked the past of the Soviet period and the present in the nineties of CIS in modern philosophy, culture, sociology, linguistics, literature, and other scientific fields is considered. The authors analyze the work of Didar Amantay in which elements of postmodernism express brightly. However, examples from his story, "I miss You" are given, in which phenomenon of postmodernism is clearly manifested.

Keywords: kazakh literature; the kazakh literary studies; modernism; postmodernism; postmodern collage; black humor; modern kazakh prose.

\section{Введение}

В мировом духовно-культурном процессе немало споров возникает вокруг явления постмодернизма. Это явление, распространившееся на всем мировом пространстве, также нашло свое отражение в разных областях науки. Не секрет, что и в искусстве слова, в художественной форме характеризующем черты общества, в последнее время ясно прослеживаются его (постмодернизма) проявления - это известный процесс в мировой литературе, который постоянно находится в состоянии развития.

Литературу, какую бы она не представляла страну, оставаясь в рамках национальной сферы, явление постмодернизма обходило стороной в потоке всемирного литературнокультурного процесса.

Если учитывать, что и казахская литература не может остаться в стороне от мирового литературного движения, то становится очевидным тот факт, что нельзя рассматривать нашу национальную литературу в отрыве от мировых закономерностей.
\end{abstract}




\section{Материалы и методы}

В настоящее время явление постмодернизма стало активно исследоваться в казахском литературоведении. В данной статье предпринята попытка проанализировать элементы постмодернизма, встречающиеся в современной казахской прозе, на материале отдельных художественных произведений Д.Амантая, как наиболее показательного в этом плане.

Среди появившихся в свет на современном этапе произведений ближе всех к эстетике постмодернизма стоят произведения писателя Дидара Амантая. В его романах «Гүлдер мен кітаптар» («Цветы и книги»), «Тоты құс түсті көбелек» («Мотылек цвета павлина»), «Шайтан мен шайыр» («Черт и пот»), повести «Мен Сізді сағынып жүрмін» («Я скучаю по вам»), в рассказе «Көзіңнен айналдым» («Мой ненаглядный») и других по сравнению с произведениями других авторов отмечается большая насыщенность посмодернистского мировидения. Романы Дидара Амантая небольшие по своему объему. Высказывались разнообразные мнения учеными, писателями, критиками о романе «Цветы и книги». Писатель-драматург Дулат Исабеков резко заявляет: «... если это называть романом, то все на свете должны изменить свое представление о романе ...его нельзя назвать романом», пишущий одинаково на казахском, русском и немецком языках Герольд Бергер отмечал: «...то, что написано Дидаром, не похоже ни на что. Написанное им - особое, не соответствует традиционным образцам. Эти особенности молодежь воспринимает хорошо, ну, а старшее поколение в корне не принимает и стоит против... А мне Дидар напоминает моего неповторимого совершенно отличного по своей природе покойного друга Аскара Сулейменова». А критик Алия Бопежанова, отмечая стремление Д. Амантая сознательно внести в нашу собственную прозу структурные изменения и что по этой причине читатель не сразу воспринимает это, высказывает следующее мнение: «Творчество Дидара отличается не бросающимся в глаза философским строением, а также жизнеспособным диалогическим характером» («Алматы ақшамы» 10.01.2011 г.) [1].

\section{Обсуждение}

Таласбек Асемкулов в своей статье «Направления в современной казахской прозе» отмечает, что «Дидар Амантай - писатель, имя которого на слуху, который является писателем, рождающим «проблему» в особенности для старшего поколения художников слова. Здесь следует отметить еще следующее. В любой литературе мира открыт путь для эксперимента. Если честно, то Дидар никогда не был против классического стиля. Он признает, что его творчество - в чистом виде эксперимент и говорит об этом... Мы должны признать, что эксперимент также имеет художественную презумпцию», далее он высказывает очень уместное мнение: «Хотя это и не понравится консерваторам казахской литературы, хочу отметить, - наш язык устарел. Я не говорю здесь о разговорном языке, об исконно правильном языке казахов. Этот язык никогда не устареет. Незаметно обновляясь, он будет жить. Я говорю об устаревании художественного языка казахского искусства. И это мнение не одного Дидара, но и меня. Большинство передовых казахских мастеров пера осознают это и даже высказываются иногда в беседах между собой. Тем не менее кажется, что между казахскими писателями существует некий неафишируемый договор. Никто не говорит прямо об устарелости художественного языка. Когда ранее я говорил о необходимости открыть дорогу эксперименту, я имел в виду это» [2].

Н. Кожабекова высказывает такое мнение о героях современной казахской прозы: «Изменения, происходящие во внешней среде, оказывают сильнейшее воздействие на сознание героев, на каждое явление сознание героя дает ответ эмоциональными импульсами», говоря так, она отмечает, что стиль произведений Дидара Амантая монотонный.

Увидевшая свет повесть Дидара Амантая последних лет «Я скучаю по Вам» совершенно отличное от традиций произведение. Это отмечается сразу в процессе чтения по строению предложения. Все в Вас бунтует против ошибок со стилистической точки зрения, однако вспоминаешь, что постмодернисты являются нарушителями всех известных канонов или сформировавшихся традиций, так как автор не может не знать о стилистическом несоответствии создаваемых им предложений. Повесть Дидара Амантая «Я скучаю по Вам» можно определить как произведение, написанное точно в русле постмодернистских 
образцов. Повесть (всего лишь в десять страниц) оставляет впечатление как сконструированное из вырванных кусков различных произведений. Нет цельного сюжета, построенного по определенной системе с разворачивающимися событиями, способного привести читателя к заданной автором идее, основной сути. На внешний взгляд, диалоги между героями не производят впечатления построений, преследующих определенную цель или обмен мыслями. Они кажутся случайными словами, оброненными помимо воли людей, не требующие ответа. Более того, они не ставят целью достичь его решения, достичь истины. Заканчивается смертью Мухтара, а дальнейшее его продолжение - ситуация, разрешаемая самим читателем. Повесть дана как постмодернистский коллаж. А постмодернистский коллаж - это явление, не совсем понятное для казахской литературы. Однако вполне законно его использование писателем в качестве эксперимента. Одна из главных особенностей постмодернизма - это постановка им знака равенства между писателем и читателем. Писатель - сам читатель написанного им произведения, один из многих читателей. При первом чтении это произведение Дидара Амантая может произвести слишком отрицательное впечатление на сформировавшиеся традиционной литературой мысли, понятия. Поскольку события даны разбросанно, небрежно, сначала дается финал (смерть Мухтара, приход и сообщение об этом Галиябану Еркину), затем снова возвращаетесь, т.е. начинается объяснение финальных событий, которые в свою очередь, не являются системными, последовательными и ясными. Разнообразные компоненты, данные в виде постмодернистского коллажа, которые вы вправе построить по своему усмотрению, однако результат, решение приводят к одной основе.

В повести показаны запутанные взаимоотношения среди молодежи, их тупиковое состояние, смерть Мухтара. В произведениях ДидараАмантая глубоко отражены чаще всего такие проблемы, как состояние современного общества, духовное обнищание молодежи.

В целом в произведениях широко изображается кризисное состояние персонажей. Особенности использования диалога могут привести читателей в заблуждение. Сначала дается разговор между Галиябану и Еркином , далее эта нить обрывается, затем приводится диалог между Мухтаром и Еркином, произошедший как раз перед смертью Мухтара. То есть использована постмодернистская литературная игровая техника. Наряду с этим неизвестно от кого это исходит, если не перечитывать, то часто будете встречать не совсем понятные философские рассуждения. Особенность автора в том, что он легко выходит с наезженной тропы, рисует обычное явление жизни и снова переходит на диалоги. Одним словом, в произведении происходит свободное движение. Главный герой Мухтар - человек, мечтающий о чистой возлюбленной, жаждущий чистого искусства. А Галиябану, жена Мухтара, человек находящийся в растерянности от того, что не знает, как развести вот это «честность, искренность в действии, или же в намерении» не догадывающаяся об истинной сущности честности и искренности. «Стыд, позор сильнее смерти», она нарушает это правило, характеризующее национальный менталитет. «Жизнь - отдельно существующее от стыда - совести понятие, поэтому стыд, позор не сильнее смерти и она не бессильна перед ней», - так думает наш персонаж, от которого мы ждем честности, искренности [3, 135]. Она - жертва соблазнителя Нурлана. То, что для Мухтара горе от любви не легко преходящее состояние, мы понимаем в процессе чтения произведения. Безвыходные действия человека, душевные страдания которого не понимает его возлюбленная. Частые переходы от диалога между героями к монологу, от монолога к диалогу, авторские рассуждения - все это особенности произведения. Например:

«- нет постоянства в нас, и мысли, и чувства в нас изменчивы, преходящие, - сказал он, не глядя на скоро шагающего Ербола.

- Да, вред от человеческих слабостей затих что ли, возможно, ему предназначены эта нескончаемая борьба, постоянные столкновения, все время расставаться.

- Пусть ждет горя, бедняга. Горе придет в обязательном порядке, единственный честный братишка, который не обманет - это оно.

Пожалуй, напрасно думает Ербол, его намерение - смерть. Из-за угла улицы показалось кафе. Устал, разочаровавшись в жизни, теперь мечтает о вечном сне, а есть ли вечный сон... Не знает, то, что называем сон-продолжение жизни. После жизни нет сна, смерть - вода, оторванная от солнечного света темная переправа. После смерти остающийся след - ничто с запахом земли. У ничего не бывает сна» [3, 135-136]. 
На такие беспокойные мысли и вопросы пытаются искать ответы наши герои. Однако вопросы бесконечны, а ответы непроницаемы, неясны. На это и нет ответа. Причина в том, что, по мнению постмодернистов, настоящей истины нет, даже если и есть, то бытие видится безрадостным. Для постмодернистов попытка решения загадок вселенной и их разрешения невозможна. Все, что нас окружает, ложно, «каждая ложь в своей горсти сохраняет одну часть правды, а в каждой истине есть хоть одна капля яда» - эти мысли постмодернистских авторов имеют место и в этом произведении.

Наряду с этим, автор преследует определенную цель, вводя в структуру произведения отрывки из других текстов. «И Абай, когда переводил Лермонтова, писал так: «Прошедшая жизнь - увиденный сон, что бы ни было - случится», - приводя этот отрывок, дает понять, что автор, хотя герой Мухтар и понимает свою вину и готовится принять смерть, отмечаешь для себя, что он очень образованный, глубоко думающий человек.

«Он уйдет, сначала заставит скорбеть, позднее долго скучать, свою неумолимо приближающуюся судьбу он давно уже предугадал, не записывая, утешения точно отделяя от написанного, любое решение скрыто преследуя», - кто так размышляет - сначала не совсем понятно, автор ли это, или Еркин. А позднее, когда читаешь повторение: «Он уйдет, сначала заставит скорбеть, позднее долго скучать, свою неумолимо приближающуюся судьбу он давно уже предугадал, Ербол», - уже конкретно понимаешь.

Не случайно и то, когда Галиябану и Нурлан повстречались, автор ставит ему (Нурлану) музыку «Only you». Сам этот факт показывает связь музыки с предстоящим текстом, сигнализирует читателю о предстоящей ситуации. В момент истины Мухтар понимает, что не хочет умирать «Не приходите ко мне, смерть, возможно, правильно увидеть все раньше, раньше людей пропустить через себя и коварство, и честность», он позднее говорит правду Ерболу о том, почему хочет умереть: «Я иду в поисках Бога... родина великого Создателя, по всей видимости, там должно быть гнездо, где повстречаются тленные вина и нрав». «Ищущий бога, он весной в апреле месяце, в пятницу в узком ущелье Медео умер, застрелившись» [3, 138].

Мухтар погиб в поисках вечной истины с чистой душой. Его подтолкнули к этому не бедность жизни, кажется, что нет в этом участия и Галиябану. Наш главный герой стал жертвой безграничной честности, ну а жизнь намного сложнее, чем мы думали. Неизвестно, встретила или не встретила истина Мухтара, пожертвовавшего жизнью в поисках истины.

\section{Выводы}

Подводя итог, можно отметить, что все молодые герои в произведениях Дидара Амантая стремятся к обретению счастья. Мечтающие о настоящем счастье, рае люди. Пытаются найти счастье в любви, при этом их чувства непостоянны. Финал трагичен разочарование (мысль Мухтара из повести «Я скучаю по Вам»). Чувство радости сменяется печалью, переходящей в глубокую скорбь, как говорил Абай Кунанбаев: «Конец жизни разочарование, для понимающего и мыслящего сознанием», - все герои Дидара Амантая, ищущие вечное счастье, жертвующие жизнью в поисках честности, справедливости. Они доказывают невозможность достижения истины (счастья, настоящего, правдивого), считающейся главным свойством, особенностью постмодернизма. Мы убеждаемся в процессе чтения, что у Дидара не только сюжет, но и в целом форма, внутреннее строение слов предложений нарушены с целью достижения авторской цели.

\section{Примечания:} 2012. $578 \mathrm{c}$.

1. Искакулы Д. Критика история литературы. Әдеби сын тарихы. Алматы: Таңбалы,

2. Асемкулов Т. Направления современной казахской прозы. - otuken.kz

3. Амантай Д. На вершине Каркаралы: романы, повесть, рассказы, эссе, стихи. Книга 1. Алматы: Жазушы, 2010. 396 с.

\section{References:}

1. Iskakuly D. Kritika istoriya literatury. Odebi syn tarikhy. Almaty: Taңbaly, 2012. 578 s.

2. Asemkulov T. Napravleniya sovremennoi kazakhskoi prozy. - otuken.kz 
3. Amantai D. Na vershine Karkaraly: romany, povest', rasskazy, esse, stikhi. Kniga 1. Almaty: Zhazushy, 2010. 396 s.

УДК 82.09”19”(574)

\title{
Әстетика постмодернизма в творчестве Дидара Амантая
}

\author{
${ }^{1}$ Саржан Такиров \\ 2Адил Жакулаев \\ ЗЖазира Алтынбекова
}

\author{
${ }^{1}$ Карагандинский государственный университет им. академика Е.А. Букетова, Казахстан \\ Кандидат филологических наук \\ ${ }^{2}$ Карагандинский государственный университет им. академика Е.А. Букетова, Казахстан \\ Магистр наук \\ ${ }^{3}$ Назарбаев Интеллектуальная школа, г. Караганда, Казахстан \\ Магистр наук \\ E-mail: sarzhan68@mail.ru
}

Аннотация. В статье рассматривается проявление постмодернизма, берущего начало в шестидесятых годах XX столетия, впитавшего прошлое советского периода и настоящее девяностых годов СНГ в современной философии, культуре, социологии, лингвистике, литературе и других научных сферах. Авторы анализируют творчество Дидара Амантая, в котором ярко проявляются элементы постмодернизма. Вместе с тем приводятся примеры его повести «Я скучаю по Вам», в которой отчетливо проявляется явление постмодернизма.

Ключевые слова: казахская литература; казахское литературоведение; модернизм; постмодернизм; постмодернистский коллаж; черный юмор; современная казахская проза. 